\title{
Opini Publik dan Politik Luar Negeri: Sikap Masyarakat Indonesia terhadap ODA Jepang dalam Proyek PLTA Koto Panjang dan Hubungan Bilateral Indonesia-Jepang ${ }^{1}$
}

\author{
Keigo Kashiwabara \\ Kedutaan Besar Jepang di Indonesia
}

\begin{abstract}
Japan has been playing an important role in the international society, especially in the field of the development of developing countries, through its ODA (Official Development Assistance). Indonesia, which has the biggest economic potential in Southeast Asia, is the largest recipient of Japanese ODA. Economic cooperation through ODA now functions as the core of the amicable bilateral relations between the two countries. However, ODA alternatively has had some negative aspects on its recipients. Some of the ODA projects (called Mondai-ankens) have actually triggered various problems at project sites and have consequently afflicted the local people. The most well-known mondai-anken that aroused national discussion on ODA policy is Koto Panjang Hydropower Plant Project implemented in Riau Province, in 1991-1997. The local community has been critical of Japanese ODA since the implementation of the project, which was done in a coercive manner under the Soeharto administration, caused costly damage to the local people such as poverty, scarcity of food, environmental destructuion, and so on. Although the mondai-anken issue caused considerable damage to the recipient country's people, and the local commnity filed a complaint to the donor country, this issue had no political impact to the bilateral relations between the two countries.
\end{abstract}

Keywords: ODA (Official Depelopment Assistance), Mondai-anken, Economic cooperation, Japan, Indonesia

\footnotetext{
Abstrak

Jepang sudah lama memiliki peran penting di dalam masyarakat internasional, khususnya dalam pembangunan negara-negara berkembang melalui pemberian ODA (Official Development Assistance). Indonesia, negara dengan potensi ekonomi terbesar di kawasan Asia Tenggara, adalah negara penerima ODA Jepang yang terbesar. Kerja sama ekonomi melalui ODA telah menjadi kunci utama untuk hubungan bilateral Jepang-

${ }^{1}$ Versi pertama artikel ini merupakan tesis MA penulis sebagai syarat menyelesaikan program S2 Ilmu Hubungan Internasional, Universitas Gadjah Mada. Penulis berhutang banyak kepada semua pihak yang telah membantu: Nur Rachmat Yuliantoro, Usmar Salam, Rochdi Mohan Nazala, Katshito Toyama, Miho Sakai, Iswadi dan keluarga, warga Koto Panjang, dan semua pihak yang telah memberikan kontribusinya.
} 
Indonesia yang lebih harmonis dewasa ini. Namun, sebetulnya ODA mempunyai sisi negatif juga. Sebagian proyek ODA (Mondai-anken, proyek bermasalah) menimbulkan berbagai masalah di lapangan dan membuat penduduk lokal menderita dampak negatifnya. Mondai-anken yang paling tipikal dan kelak memberikan kesempatan untuk perdebatan di masyarakat Jepang adalah pembangunan proyek PLTA Koto Panjang yang dilaksanakan di Provinsi Riau pada tahun 1991-1997. Masyarakat Koto Panjang bersikap kritis terhadap ODA Jepang dalam proyek pembangunan PLTA karena proyek tersebut mengakibatkan kerugian drastis bagi mereka, seperti kemiskinan, kelaparan, kerusakan lingkungan hidup dan lain-lain sebagai akibat dari pelaksanaan proyek secara paska oleh pemerintah Indonesia di bawah kepemimpinan Presiden Soeharto. Walaupun permasalahan yang disebabkan mondai-anken tersebut telah mengakibatkan kerugian serius bagi warga negara penerima, apalagi masyarakat lokalnya menggugat pemerintah negara donor, hal ini tidak berdampak apa pun terhadap hubungan kedua negara secara politik.

Kata-kata kunci: ODA (Official Depelopment Assistance), Mondai-anken, kerja sama ekonomi, Jepang, Indonesia

\section{Pendahuluan}

Tulisan ini meneliti kebijakan ODA (Official Development Assistance) Jepang di Indonesia, terutama masalah-masalahnya dilihat dari kasus yang terjadi di Koto Panjang, Provinsi Riau. Penulis memilih tema ini karena sebagai orang Jepang penulis ingin memperdalam pengetahuan mengenai ODA Jepang. Bagi negara-negara yang tidak mempunyai atau menggunakan kekuatan militer seperti Jepang, ODA adalah salah satu alat diplomasi yang paling penting dan efektif. Dalam konteks ini, penelitian tentang ODA sangat berarti untuk menganalisis praktik diplomasi Jepang dan membuat proyeksi masa depannya. Bagi penulis yang bekerja untuk memperdalam hubungan bilateral Jepang-Indonesia, analisis mengenai ODA Jepang di Indonesia juga sangat signifikan mengingat kebijakan ODA Jepang di Indonesia sangat berpengaruh terhadap hubungan kedua negara. Melalui kasus Koto Panjang, penulis ingin menganalisis sisi negatif ODA, seperti apa yang terjadi sebenarnya pada proyek yang bermasalah, dan bagaimana implikasi sikap masyarakat terhadap proyek Koto Panjang terhadap kebijakan ODA Jepang atau hubungan bilateral Jepang-Indonesia. Penulis juga melakukan penelitian lapangan untuk melihat proyek ODA secara langsung dan memahami bagaimana kondisi sebenarnya. Hal ini sangat membantu membuat isi tesis ini lebih reliable.

Seperti telah disampaikan di atas, ODA adalah salah satu alat diplomasi terpenting Jepang. Indonesia, sebagai salah satu negara mitra pembangunan Jepang, telah mendapatkan manfaat dari ODA sejak lama. 
Sebagai upaya untuk mewujudkan pembangunan ekonomi dan sosial Indonesia, pemerintah Jepang selama lebih dari 50 tahun telah berkontribusi mendukung Indonesia dalam berbagai bentuk, seperti bantuan aliran dana, teknologi, dan bantuan darurat korban bencana alam. ODA Jepang di Indonesia dimulai sejak tahun 1954 dalam bentuk penerimaan trainee untuk mendapatkan pelatihan di bidang industri, komunikasi, transportasi, pertanian dan kesehatan. ODA Jepang telah memberikan kontribusi besar di bidang pengembangan sumber daya manusia dan pembangunan infrastruktur sosial ekonomi Indonesia. Misalnya, pada saat krisis ekonomi melanda Asia pada tahun-tahun 19971998, Jepang membantu Indonesia yang sedang berusaha keluar dari krisis dalam bentuk pinjaman khusus, perpanjangan kewajiban pembayaran, dukungan strategi pemerintah, dan lain-lain. Begitu pula ketika gempa besar dan tsunami dari lautan Hindia melanda pulau Sumatera pada Desember 2004, Jepang menyediakan dana rekonstruksi dan rehabilitasi untuk korban bencana sebesar $\$ 640$ juta.

Selama ini, secara kumulatif, bantuan Jepang kepada Indonesia telah berjumlah \$34,9 miliar (total sampai tahun 2011). Pada tahun 2011 besar bantuan Jepang kepada Indonesia adalah \$860 juta. Bagi Indonesia, Jepang adalah negara donor terbesar; demikian juga bagi Jepang, Indonesia adalah negara penerima bantuan terbesar (Kedutaan Besar Jepang di Indonesia, n.a). Dengan latar belakang ini, Jepang dan Indonesia telah memupuk hubungan persahabatan selama lebih dari setengah abad; kedua negara ini telah menjadi mitra penting secara timbal-balik. Namun demikan, ternyata tidak semua ODA Jepang dilaksanakan dengan lancar dan efektif serta menghasilkan manfaat untuk negara penerima. Dalam banyak proyek bantuan Jepang, ada beberapa yang dianggap sebagai "Mondai-anken (proyek yang bermasalah)." Salah satunya adalah proyek pembangunan Pembangkit Listrik Tenaga Air (PLTA) Koto Panjang, yang terletak di Provinsi Riau. Proyek yang dijalankan dengan skema pinjaman Yen² pada tahun 1993-1996 ini adalah proyek pembangunan sebuah

\footnotetext{
2 Pinjaman Yen adalah pinjaman dana dengan persyaratan ringan, yaitu berjangka panjang dan berbunga rendah, yang dibutuhkan oleh negara berkembang dalam rangka menata pondasi sosial ekonomi mereka sebagai dasar dari pembangunan. Pinjaman Yen ini dilaksanakan melalui Japan Bank for International Cooperation (JBIC). Selain skema ini, ada skema bantuan dana hibah, yang tidak disertai dengan kewajiban untuk membayar kembali, dan kerja sama teknik yang diberikan untuk membantu pengembangan SDM di negara-negara berkembang. Agar setiap negara dapat berkembang, mutlak diperlukan "upaya pembangunan manusia" yang akan memegang peranan di dalam perkembangan sosial ekonomi. Agar teknik dan pengetahuan yang telah dibangun oleh Jepang dapat dialihkan kepada para teknisi dan pejabat dari negara berkembang, maka Jepang mengundang tenaga magang, mengirim tenaga ahli dan relawan, mengirim bantuan mesin dan
} 
bendungan yang dirancang oleh perusahaan Jepang TEPSCO (Tokyo Electric Power Services). Damnya sudah dibangun dan aktif, tetapi pada bulan September 2002 pemerintah Jepang, JICA (Japan International Cooperation Agency) dan TEPSCO dituntut untuk memberikan kompensasi kira-kira ¥20 milyar (sekitar Rp 2 trilyun) oleh penduduk yang berdiam di wilayah sekitar proyek tersebut yang berjumlah 3.861 orang. Menurut para penduduk, mereka dipaksa pindah ke desa yang terpencil dan semua rumah atau tanah pertanian milik mereka disita pemerintah tanpa izin untuk pembangunan proyek tersebut. Apalagi, proyek itu dipercaya telah membuat ekosistem di wilayah pembangunan dam menjadi rusak sehingga beberapa jenis hewan liar seperti gajah dan harimau Sumatera tidak bisa hidup lagi di sana.

Para penduduk yang dikecewakan mengajukan klaim kompensasi di atas ke pengadilan tinggi Tokyo, tetapi pengadilan menolak klaim tersebut karena kasus ini dianggap sebagai urusan internal Indonesia. Sekarang para pengklaim ini sedang mengupayakan naik banding dalam kasus tersebut. Apa yang istimewa dan berbeda dengan Mondai-anken yang lain adalah bahwa proyek Koto Panjang ini adalah satu-satunya proyek yang mengakibatkan gugatan oleh penduduk di negara penerima di dalam sejarah ODA Jepang. Kasus ini memperlihatkan bahwa di samping manfaat dan keuntungan yang normalnya diperoleh dari ODA, sesungguhnya terdapat juga beberapa aspek negatif ODA Jepang yang harus diperbaiki. Oleh sebab itu pertanyaan-pertanyaan yang penting untuk diajukan adalah: (1) Mengapa masyarakat Koto Panjang Riau bersikap kritis terhadap ODA Jepang dalam proyek pembangunan PLTA Koto Panjang? (2) Apa dampak dari sikap kritis masyarakat Koto Panjang Riau terhadap PLTA Koto Panjang bagi kebijakan ODA Jepang dan hubungan Jepang-Indonesia?

ODA adalah bantuan ekonomi buat negara-negara berkembang sebagai alat diplomasi yang sangat efektif bagi negara-negara yang memiliki kekuatan ekonomi besar, khususnya bagi negara-negara yang tidak bisa secara leluasa menggunakan kekuatan militernya untuk mendapatkan pengaruh dalam politik internasional. Menurut Japan's ODA White Paper 2012, kebijakan ODA ditentukan dan dilaksanakan berdasarkan tiga prinsip: (1) Jepang memberikan ODA kepada negara yang mempunyai nilai-nilai kebebasan dan domokrasi; (2) Jepang 
mementingkan perlindungan hidup individu atau harga diri individu (human security); dan (3) melalui ODA, Jepang mendukung ekspor infrastruktur buatan Jepang yang terbaru dan tercanggih di dunia. Jepang membuat kebijakan ODA yang memungkinkan baik Jepang maupun negara-negara penerima dapat mengembangkan perekonomian mereka.

Tulisan ini berpendapat bahwa ODA tidak hanya diberikan untuk alasan kepentingan nasional saja. Meski demikian tulisan ini juga tidak sepakat dengan ODA yang dijalankan tanpa strategi diplomatik. Tulisan ini memberikan penilaian positif terhadap kebijakan ODA yang seimbang antara kedua aspek di atas. Tulisan ini memandang bahwa kasus gugutan yang terjadi dalam proyek pembangunan PLTA Koto Panjang disebabkan oleh dua hal yaitu kedua pemerintah dengan sengaja menutup mata terhadap risiko-risiko tersebut demi melaksanakan proyek dan menjaga kepentingan nasional masing-masing dan aturan-aturan di kontrak proyek tersebut tidak cukup jelas. Kedua hal tersebut bisa terjadi di sebagian proyek ODA Jepang yang lain juga, yang umumnya terjadi karena kepentingan nasional negara donor lebih dipentingkan daripada tujuan ODA yang sesungguhnya, yaitu pembangunan dan kemajuan ekonomi negara penerima.

Tulisan ini akan dibagi menjadi tiga bagian. Bagian pertama membahas proyek PLTA Koto Panjang di Riau. Bagian ini akan menelusuri sejarah dibangunnya PLTA Koto Panjang di Riau; bagaimana peran pemerintah Jepang melalui ODA sampai timbul protes dari masyarakat setempat akibat dampak negatif yang ditimbulkannya. Bagian kedua membahas dampak gugatan tersebut terhadap hubungan bilateral Indonesia-Jepang. Pembahasan akan difokuskan pada prospek kerjasama ekonomi antar kedua negara. Bagian ketiga adalah kesimpulan yang berisi penekanan argumen utama dan implikasinya bagi hubungan bilateral kedua negara.

\section{Proyek PLTA Koto Panjang Riau Sebagai Mondai-Anken}

Pada tahun 1979, PLN (Perusahaan Listrik Negara) merencanakan pembangunan sebuah PLTA (Pembangkit Listrik Tenaga Air) di Tanjung Pauh, Kabupaten Limapuluh Kota, Provinsi Sumatera Barat. Tujuan utama rencana proyek ini ialah menambah daya listrik di kawasan sekitar, termasuk juga beberapa daerah di provinsi tetangga Riau. Di tahun 1980an, dengan perkembangan ekonomi secara drastis di daerah Sumatera, permintaan listrik di daerah tersebut bertambah lebih dari 20\% (JBIC, 2002:10). Pada tahun 1988, sumber listrik di Provinsi Sumatera Barat 
berasal dari tenaga air $(46,9 \%)$, tenaga gas $(25,7 \%)$, dan tenaga diesel (27,4\%). Provinsi Riau menghasilkan 100\% listrik dari pembangkit listrik tenaga diesel. Di Sumatera Barat, kabel listrik disediakan hanya di kota Padang dan daerah sekitarnya, sementara penduduk di Provinsi Riau menggunakan listrik lewat pembangkit listrik tenaga diesel yang berskala kecil dengan kabel yang disediakan oleh penduduknya sendiri. Oleh sebab itu, electrification rate di Provinsi Riau hanya sampai 12,3\% saja; ini adalah persentase paling rendah di seluruh pulau Sumatera yang mempunyai rata-rata electrification rate $24,9 \%$ (JBIC, 2002:10).

PLN tidak mampu meningkatkan tingkat penyediaan listrik di Riau karena tidak tersedia cukup sumber daya alam yang dibutuhkan untuk pembangkitan, seperti gas alam atau sumber daya panas bumi. PLN kemudian memutuskan untuk membangun PLTA Kota Panjang yang berskala besar (114 Megawatt) dengan dana sekitar \$251 juta atau sekitar $¥ 31,2$ milyar pada waktu itu dengan memanfaatkan sumber daya air di Riau dan memenuhi kebutuhan listrik penduduk di provinsi tersebut. PLN juga merencanakan persiapan kabel listrik yang menyambungkan PLTA Koto Panjang dengan Provinsi Sumatera Barat dan Provinsi Riau untuk mengirimkan listrik yang dihasilkan PLTA tersebut atau listrik yang tersisa di Provinsi Sumatera Barat ke Provinsi Riau sehingga keseimbangan permintaan dan penawaran listrik di kedua daerah terjaga. Keputusan PLTA ini berdasarkan saran dari TEPSCO (Tokyo Electric Power Services Corporation) yang nanti akan menjadi pembangun PLTA tersebut.

Menanggapi rencana pembangunan PLTA Koto Panjang, pemerintah Indonesia meminta pelaksanaan studi kelayakan untuk proyek ini kepada pemerintah Jepang pada Juni 1981. Studi kelayakan dilaksanakan TEPSCO pada kurun waktu Januari 1982- Maret 1984 dan dari studi ini disimpulkan bahwa proyek tersebut dapat dilaksanakan. Lewat studi tersebut tujuan proyek ini ditentukan, yaitu memenuhi kebutuhan listrik di Provinsi Riau dan Provinsi Sumatera Barat serta memperbaiki standar kehidupan penduduk dengan meningkatkan sarana kelistrikan di kedua daerah tersebut. Namun setelah studi kelayakan selesai, sering muncul protes mengenai proyek ini dari penduduk di kedua daerah. Masyarakat Kabupaten Kampar, Provinsi Riau, misalnya, tidak setuju dengan pembangunan bendungan ini mengingat dampak negatif yang kelak akan dihasilkan. Media Jepang juga memberitakan adanya kemungkinan kerusakan lingkungan berkaitan dengan proyek Kota Panjang sehingga mengundang suatu tim swasta untuk melihat 
langsung kondisi di lapangan. Tim ini kemudian meminta pemerintah Jepang untuk menghentikan pinjaman untuk pelaksanaan proyek PLTA Kota Panjang. Permintaan tim ini menimbulkan perdebatan di Jepang tentang apakah proyek ini harus dilanjutkan atau dibatalkan. Menanggapi ini pemerintah Jepang mengirim tim riset OECF (Overseas Economic Cooperation Fund, nanti akan menjadi JBIC pada tahun 1999) ke lapangan untuk kembali melaksanakan studi kelayakan. Hasil studi kelayakan kedua ini menyimpulkan bahwa proyek Koto Panjang dapat dilaksanakan.

Pada bulan Desember 1990, pemerintah Jepang dan Indonesia menandatangani kesepakatan Exchange Note atas proyek Kota Panjang dengan nama "Kota Panjang Hydroelectric Power and Associated Transmission Line Project." Tokyo kemudian menurunkan dana bantuan pertama senilai $¥ 12,5$ milyar. Di tengah gelombang protes dari masyarakat setempat, pemerintah Jepang mengajukan syarat-syarat bagi pinjaman tersebut untuk pembangunan PLTA Kota Panjang (syarat-syarat ini tidak diumumkan kepada masyarakat secara resmi sehingga isinya sedikit berbeda tergantung sumbernya): gajah yang bermukim di lokasi harus diselamatkan dengan memindahkannya ke tempat perlindungan yang cocok; tingkat kehidupan keluarga yang terkena dampak dari proyek Koto Panjang di pemukiman baru harus sama atau lebih baik dari pada di tempat awal; persetujuan pemindahan bagi yang terkena dampak proyek harus dilakukan secara adil dan merata; setiap kepala keluarga yang terkena dampak proyek harus menyatakan bahwa mereka sudah siap untuk pemindahan (persetujuan hanya oleh ketua komunitas di lapangan tidak cukup, harus disetujui setiap kepala keluarga); penduduk yang terkena dampak dari proyek Koto Panjang harus mengikuti perundingan pembayaran ganti rugi; segala hewan liar, terutama 30 ekor gajah, di lokasi harus diselamatkan dengan dipindahkan ke tempat pelindungan yang cocok (Sumi, 2006:37).

Inilah kali pertama dalam sejarah ODA Jepang bahwa Tokyo mengajukan syarat-syarat untuk sebuah proyek ODA kepada negara penerima. Pemerintah Indonesia mengklaim bahwa tindakan Jepang tersebut adalah suatu intervensi terhadap urusan domestik, namun syarat-syarat ini menjadi semacam tiket bagi pemerintah Indonesia untuk mendapatkan pancairan dana pinjaman tersebut. Rencana pembangunan kemudian sempat terganggu dengan kedatangan dua orang wakil penduduk Koto Panjang yang melapor ke kantor OECF di Jakarta bahwa persetujuan masyarakat untuk pemindahan dan kompensasi sebetulnya 
merupakan hasil dari intimidasi. Namun, aspirasi mereka tidak didengarkan dengan alasan "tidak resmi" (Sumi, 2006:38). Pada bulan Mei 1991, Hira Jhamtani, Direktor Eksekutif SKEPHI (Sekretariat Kerjasama Pelestarian Hutan Indonesia) mengunjungi Departemen Luar Negeri Jepang di Tokyo untuk mengklaim bahwa syarat-syarat di atas tidak cukup dipenuhi oleh pemerintah Indonesia. Ia juga meminta agar pemerintah Jepang mengirim tim pengawas untuk memeriksa hal tersebut. Permintaan pengiriman tim pengawas tidak dikabulkan oleh pemerintah Jepang, tetapi pemerintah Jepang menegaskan bahwa ia akan berusaha memeriksa apakah proses pembangunan proyek Kota Panjang telah berjalan sesuai dengan syarat-syarat yang ditetapkan dari laporan pemerintah Indonesia. Pemerintah Jepang juga menanggapi pemerintah Indonesia dengan menyerahkan rencana aksi (action plan) menyangkut ketiga syarat pada bulan Oktober 1991. Dua bulan kemudian, dana pinjaman kedua senilai $¥ 17,525$ milyar dicairkan.

Pembangunan proyek Kota Panjang kemudian dimulai seiring dengan pemindahan secara bertahap penduduk di sekitar lokasi ke pemukiman baru. Jumlah penduduk yang dipindahkan ke pemukiman baru (Project Affected Families) sebesar 4886 keluarga di 10 desa (Vesky, 2014:1). TEPSCO yang berperan dari awal proyek ini direncanakan dikontrak lagi untuk manjadi pengawas proyek, sementara untuk pembangunan bendungan dipegang oleh Hazama Corporation. Proyek ini mencanangkan pembangunan bendungan dengan tinggi 58 meter dan panjang 258 meter, yang kelak akan merendam wilayah seluas 124 kilometer persegi dengan target energi listrik $114 \mathrm{MW}$.

Ketika proyek ini sedang berjalan, diberitakan pula bahwa beberapa kali ada warga masyarakat yang mendatangi pemerintah daerah Riau maupun Sumatera Barat untuk menuntut kompensasi pemindahan yang belum dibayar. Karena tidak mendapat respon yang serius, masyarakat membawa kasus ini ke Komisi Nasional HAM. Menurut penelitian oleh tim SAPS JBIC dan studi lapangan penulis sendiri, persoalan utama kasus ganti rugi ini adalah sebagai berikut: kompensasi untuk beberapa kepala keluarga belum dibayar sama sekali; harga pembebasan tanah terlalu murah serta merupakan hasil dari pemaksaan dan intimidasi; kompensasi umumnya dijanjikan dibayar dalam bentuk perkebunan karet dan fasilitas air, tetapi ternyata hanya ada beberapa pohon karet yang masih muda dan butuh waktu beberapa tahun lagi untuk berproduksi serta sebuah sumur yang disediakan oleh OECF, tetapi 
airnya keruh dan tidak cocok dikonsumsi (JBIC, 2002 \& wawancara dengan penduduk lokal, 26-30 Januari 2014).

Masa pembangunan ini ditandai pula dengan kondisi kesejahteraan penduduk yang dipindahkan semakin memburuk. Berubah profesi menjadi buruh kasar, pergi ke desa lain untuk bekerja di perkebunan karet yang sudah matang, dan meninggalkan anak-anak yang harus putus sekolah karena ketiadaan biaya menjadi fenomena serius pada saat itu. Namun demikian, proyek Koto Panjang tetap berjalan dan selesai pada bulan Desember 1997.

Setelah selesai dibangun bulan Maret 1996, pada bulan Februari 1997 proyek Koto Panjang dibuka dengan melakukan penggenangan secara resmi. Penggenangan ini dilakukan dengan cara menurunkan pintu-pintu sekat air bendunngan. Pada bulan Oktober 1998 akhirnya PLTA Koto Panjang mulai beroperasi. Persoalan kemudian muncul ketika di beberapa lokasi terjadi banjir besar yang tidak normal, yang sesudah diselidiki ternyata disebabkan aliran air yang terhambat akibat pembangunan bendungan Koto Panjang.

Kontroversi yang terjadi di dalam pembangunan bendungan tersebut bukan banjir besar ini saja. Menurut Takahashi (2002) dan Yamamoto (2011), setidaknya terdapat empat persoalan akibat pembangunan PLTA Koto Panjang, yaitu bahwa: kapasitas tenaga listrik 114 MW yang direncanakan hanya terpenuhi 17 MW (hanya 10\% lebih); ketinggalan air pada reservoir air di bawah titik minimum untuk membangkitkan tenaga listrik $114 \mathrm{MW}$; dari tiga generator yang digunakan, hanya Unit 1 yang bekerja penuh; ketiganya hanya digunakan secara bersama-sama pada waktu tertentu - sejak mulai beroperasi, Unit 2 dan Unit 3 pernah berhenti operasinya berkali-kali untuk pergantian sekrup yang rusak; dan penelitian WALHI (Wahana Lingkungan Hidup Indonesia) menunjukkan bahwa beberapa jenis hewan seperti gajah, harimau sumatera, dan tapir kehilangan habitat; ini mengancamkan kelestarian hidup hewan-hewan tersebut.

Menurut penduduk lokal yang dibujuk dan dipaksa meninggalkan kampung lama (4.866 keluarga dari 10 desa), proyek PLTA Koto Panjang yang memakan waktu pembangunan selama kira-kira 14 tahun ini memiliki beberapa dimensi persoalan: pertama, tidak dilibatkannya penduduk di lokasi proyek dalam pengambilan keputusan. Para penduduk hanyalah objek dari keputusan pemerintah Jepang dan Indonesia yang akhirnya menyetujui proyek ini. Apalagi pada saat itu sistem pemerintahan Indonesia masih tidak cukup demokratis di bawah 
pemerintahan Soeharto sehingga masyarakat tidak berani bersuara untuk menentang pelaksanaan proyek ini. Penduduk "dibujuk dan dipaksa meninggalkan tanah leluhur mereka" (Vesky, 2014:1). Kedua, pemukiman baru justru menghancurkan tatanan kehidupan masyarakat yang dipindahkan. Hal ini menjadi kasus terutama dalam hal mata pencaharian yang jauh di bawah standar dari apa yang mereka peroleh sebelumnya. Ketiga, terganggunya kehidupan tradisional rakyat Minangkabau yang dipindahkan. Beberapa jenis upacara/adat tradisional Minangkabau, seperti upacara tahun baru khas Minangkabau yang diadakan di sungai (pacu sampan), upacara kelahiran bayi (orang tua memandikan anaknya di sungai), dan sebagainya tidak diadakan lagi karena tidak ada sungai di pemukiman baru. Rumah gadang (rumah tradisional Minangkabau, berfungsi sebagai tempat pertemuan kepala-kepala desa) juga tidak ada lagi dan sistem musyawarah tradisional sudah menghilang. Keempat, kehancuran ekosistem dan dampaknya pada biodiversity. Kelestarian beberapa jenis hewan yang sebelumnya tidak terganggu, seperti harimau dan gajah sematera, tapir, beruang madu, rusa, dan sebagainya menjadi sebuah masalah baru karena habitat mereka terganggu oleh pembangunan proyek. Kelima, kapasitas listrik yang tidak sesuai rencana. Setelah pembangunan proyek selesai, kapasitas pembangkit listrik ini ternyata tidak setinggi yang diharapkan karena ketinggian air pada reservoir tidak maksimal. Hal ini menimbulkan masalah baru pada pemerintah Indonesia, terutama PLN, untuk membayar kembali pinjaman dari pemerintah Jepang.

Banyak penduduk setempat yang merasakan dampak negatif lebih besar daripada dampak positif bagi penduduk di Kota Panjang, sehingga pada tanggal 7 November 2001, perwakilan dari sepuluh desa yang terendam air mengorganisasikan Badan Perjuangan Rakyat Korban Dam Koto Panjang (BP RKDKP). Pembentukan gerakan ini menandai dimulainya upaya untuk menuntut pemerintah Indonesia dan pemerintah Jepang ke pengadilan. BP RKDKP didukung oleh para cendekiawan, pengacara atau LSM Jepang dan Indonesia, seperti コトパンジャン・ダム被害者住民を支援する会 (The Support Action Center for Kotopanjang Dam Victims)，インドネシア民主化ネットワーク(Netwok for Indonesian Democracy, Japan : NINDJA), Wahana Lingkungan Hidup Indonesia (WALHI) dan sebagainya. Mereka mengkritik kebijakan ODA Jepang yang mendanai proyek-proyek pembangunan yang berdampak negatif terhadap lingkungan hidup. BP RKDLP mendapatkan bantuan dana dari para pendukung tersebut, dan aktifitas mereka selalu didorong 
LSM Jepang melalui berbagai bantuan, terutama bantuan ekonomi. Bisa dikatakan bahwa dukungan dari pihak tersebut sangat penting dalam kegiatan BP RKDLP dan merupakan salah satu insentif tuntutan mereka kepada pemerintah.

Setelah kongres di Padang pada Mei 2002, dihadiri lima orang pengacara dan dosen dari Jepang, BP RKDKP memutuskan untuk menggugat kedua pemerintah dengan slogan "Bersatu Melawan Penindasan" (Sumi, 2006:475). Berdasarkan keputusan di kongres, pada 5 September 2002 sebanyak 3.861 warga penduduk menggugat Departemen Luar Negeri Jepang, JICA, JBIC, dan TEPCO ke Pengadilan Tokyo. Mereka meminta pembayaran ganti rugi sebanyak $¥ 19,3$ milyar, sekitar $¥ 5$ juta per orang, dan juga meminta pemerintah Jepang memberikan "nasihat" kepada pemerintah Indonesia agar melakukan restitution dengan penghancuran bendungan Koto Panjang. Gugatan ini diikuti gugatan kedua pada 28 Maret 2003, dengan 4.535 orang penggugat baru. Isi permintaannya sama dengan gugatan pertama, namun dengan jumlah penggugat lebih banyak sehingga pembayaran ganti rugi yang dituntut sampai berjumlah $¥ 22,6$ milyar. Di kedua gugatan para penggugat diberikan bantuan ekonomi sebanyak $¥ 50$ ribu (sekitar Rp 5 juta) dari Pengadilan Tokyo karena kondisi perekonomian mereka memang kurang cukup untuk mengikuti persidangan.

Setalah pemeriksaan-pemeriksaan dalam 25 kali sidang pengadilan, pada September 2009 Pengadilan Tokyo mengeluarkan keputusan bahwa permintaan penggugat tidak bisa diterima. Pertama, berdasarkan "political question doctrine," Pengadilan Tokyo menerangkan bahwa permintaan penggugat terhadap pemerintah Jepang agar memberikan "nasihat" kepada pemerintah Indonesia untuk menghapuskan PLTA Koto Panjang bersifat sangat politik dan tidak dapat diterima karena bila diterima maka ia kemungkinan besar dianggap melebihi wewenang pengadilan. Kedua, pembayaran ganti rugi juga ditolak Pengadilan Tokyo karena tidak ada kesalahan atau kecerobohan pemerintah Jepang, JICA, JBIC dan TEPCO yang dapat merupakan sebuah "illegal act." Pengadilan memang mencatat terdapat "kesalahan atau kecerobohan" dalam kasus ini yang mengacu pada pelanggaran "duty of care," namun pengadilan segera menjelaskan bahwa di sini pemerintah Jepang tidak mempunyai kewajiban "duty of care" terhadap warga negara asing. Menurut keputusan pengadilan, Jepang tidak bisa bertanggung jawab secara hukum atas permasalahan proyek ini karena permasalahan-permasalahan tersebut adalah masalah domestik Indonesia; sekalipun dana pembangunan proyek berasal dari 
pemerintah Jepang, proyek ini sendiri direncanakan dan dilaksanakan berdasarkan permintaan pemerintah Indonesia. Oleh karena itu, pengadilan menganggap bahwa pengelolaan dan pengendalian terhadap proyek ini harus dilakukan dengan baik oleh pemerintah Indonesia.

Setelah keputusan penolakan gugatan dari Pengadilan Tokyo, para penggugat segera naik banding dengan kasus mereka ke Pengadilan Tinggi Tokyo. Jumlah penggugatnya sebanyak 5.921 warga. Namun, gugatan mereka kembali ditolak pada 26 Desember 2012. Setelah itu, para penggugat naik banding lagi ke Mahkamah Agung Jepang dan saat ini mereka sedang menunggu hasil dari permohonan pemeriksaan kembali. Jika permohonan mereka tidak diterima dan ganti kerugian yang mereka ajukan tidak diakui oleh Mahkamah Agung, itu berarti bahwa sesuai dengan aturan sistem hukum Jepang mereka tidak memiliki kesempatan lagi untuk menuntut pemerintah Jepang. Menurut Iswadi AS, Sekjen Badan Pelaksana BP RKDKP, walaupun gugatan di Jepang ini diakhiri dengan kegagalan, mereka berniat untuk tetap berjuang dan berupaya untuk mendapatkan kompensasi dari pemerintah Indonesia dan Jepang. Menurut Iswadi, hal itu akan ditempuh dengan mengajukan tuntutan ke pengadilan internasional, melakukan kampanye di organisasi internasional seperti Perserikatan Bangsa-Bangsa (PBB), dan sebagainya.

Proyek PLTA Koto Panjang mengakibatkan bermacam-macam penderitaan bagi para penduduk lokal dengan pemindahan secara paksa, kompensasi dari pemerintah yang tidak mencukupi, dan sebagainya, sehingga masyarakat Koto Panjang bersikap kritis terhadap proyek ini dan menilai bahwa ODA Jepang tidak memperhatikan kepentingan masyarakat di lapangan. ODA Jepang bahkan dianggap hanya menawarkan dana dan membiarkan negara penerima menangani pelaksanaan proyeknya. Masyarakat memutuskan untuk berjuang supaya mendapatkan kompensasi dari pemerintah Jepang, namun tuntutan mereka ditolak dengan alasan bahwa itu adalah "masalah domestik Indonesia."

\section{Dampak Gugatan Masyarakat Koto Panjang terhadap Hubungan Bilateral Indonesia-Jepang}

Seperti telah dijelaskan, masalah-masalah yang terjadi pada ODA Jepang di proyek Koto Panjang memberi tekanan kepada pemerintah Jepang untuk membuka peluang bagi kebijakan ODA yang bersifat lebih transparan, efektif dan efisien di masa depan. Salah satu dampak proyek itu terhadap kebijakan ODA Jepang adalah revisi ODA Charter, peraturan 
dasar kebijakan ODA Jepang yang ditetapkan pemerinah pada tahun 1992. ODA Charter baru yang direvisi oleh keputusan kabinet pada tahun 2002 menunjukkan tindakan-tindakan yang harus dilaksanakan oleh pemerintah untuk membuat ODA Jepang lebih efisien dan efektif dengan berdasarkan tiga aspek, yaitu sistem perencanaan dan pelaksanaan kebijakan, peningkatan partisipasi publik, serta pelaksanaan kerja sama ekonomi internasional yang strategis dan efektif.

Aturan-aturan terinci dari ODA Charter hasil revisi antara lain: Pertama, Departmen Luar Negeri Jepang mereorganisasi Bagian Kerja Sama Ekonomi menjadi Bagian Kerja SamaInternasional pada Agusutus 2006. Bagian baru ini bertugas untuk merencanakan segala kebijakan mengenai ODA secara lengkap, memperkuat strategi kerja sama internasional, dan berusaha untuk melaksanakan kebijakan ODA yang lebih efektif dan lebih berfokus kepada kebutuhan rakyat negara penerimanya. Kedua, agar kerja sama antara pemerintah dan organisasi pelaksana ODA makin lancar, JICA, yang berperan melaksanakan proyek kerja sama teknis dan bantuan hibah, dan JBIC, yang menjalankan proyek pinjaman-pinjaman yen, digabung menjadi satu JICA pada Oktober 2008. Ketiga, untuk menjalankan program-program bantuan pembangunan yang efektif sebisa mungkin, pemerintah Jepang bertindak dengan berbagi kesadaran/ pengertian masing-masing melalui "policy consultations" dengan negara penerima ODA. Keempat, untuk memperkuat tindakan "policy consultations", di hampir semua negara penerima terdapat ODA Task Forces yang ditempatkan di kedutaan besar/konsulat Jepang atau kantor JICA. ODA Task Force tersebut membahas kebutuhan negara penerima dan mengikuti proses pengambilan keputusan kebijakan ODA kepada negara tersebut. Mulai tahun fiskal 2006 Jepang juga menempatkan Economic Cooperation Coordinator atau Keizai Kyouryoku Chouseiin (MOFA, 2013:147). di sebagian kedutaan besarnya, termasuk Indonesia, untuk memperkuat kerja sama dengan negara donor yang lain di proses pelaksanaan proyek ODA supaya efek proyek tersebut dapat meningkat.

Agar ODA bersifat lebih transparan, selain bekerja sama dengan negara donor seperti dijelaskan di atas, Jepang juga melakukan kerja sama dengan lembaga swadaya masyarakat (LSM), perusahaan swasta, universitas, pemerintah daerah, organisasi internasional, dan lain-lain untuk pelaksanaan ODA. Salah satu contoh usaha pemerintah Jepang tersebut adalah skema “日本NGO連携無償資金協力(Nihon NGO renkei mushou shikin kyouryoku, Bantuan Hibah LSM Jepang)." Sejumlah 46 LSM 
melaksanakan 92 proyek (dua kali lipat dibanding lima tahun sebelumnya), seperti pembangunan sekolah, bantuan bagi orang-orang cacat, pelatihan kerja, perbaikan kesehatan ibu dan anak, dan lain-lain, pada tahun fiskal 2012 (MOFA, 2013:148).

Reformasi atas ODA Jepang yang terjadi setelah proyek Koto Panjang dan gugatan oleh penduduk lokalnya telah mempengaruhi/mengubah sistem kebijakan ODA Jepang secara dramatis sehingga menjadi lebih transparan dan terbuka bagi rakyatnya. Perubahan ini masih terus berproses, namun setidaknya bisa dikatakan bahwa proyek Koto Panjang berdampak terhadap kebijakan bantuan ekonomi Jepang. Bila dilihat dari pernyataan pada konferensi tingkat tinggi antara Jepang dan Indonesia akhir-akhir ini, hubungan ekonomi masih menjadi prioritas dalam hubungan diplomasi antara kedua negara. Selain pernyataan mengenai pemberian ODA sebanyak $¥ 2$ trilyun untuk negara-negara anggota ASEAN pada ASEAN-Japan Commemorative Summit pada Desember 2013, pada pertemuan tingkat tinggi Jepang-Indonesia di bulan yang sama PM Shinzo Abe juga mengatakan bahwa Jepang akan memperkuat kerja sama ekonomi dengan Indonesia, terutama di bidang perdagangan, investasi, dan persiapan infrastruktur sehingga membuat hubungan politik Jepang-Indonesia bersifat "WIN-WIN". PM Abe juga menegaskan bahwa Jepang telah siap memberikan pinjaman sebanyak $¥$ 62 milyar untuk membiayai tujuh proyek, memberikan ODA juga di bidang energi, pencegahan bencana alam, dan sebagainya (MOFA, n.a).

Pada pertemuan para menteri luar negeri Jepang dan Indonesia pada Maret 2014 di Jakarta, Menlu Jepang Fumio Kishida juga menyatakan bahwa E/N dari ke-7 proyek pinjaman yen tersebut telah ditandatangani dan akan segera mulai dilaksanakan. Di pertemuan tersebut kedua negara menyetujui bahwa mereka akan mengadakan pertemuan $2+2$ (pertemuan yang dihadiri oleh menteri luar negeri dan menteri pertahanan kedua negara) dalam waktu dekat untuk kerja sama di bidang pertahanan agar mereka dapat berkontribusi bagi kestabilan kawasan, berdasarkan keeratan hubungan kedua negara di bidang ekonomi (Watanabe, 2014).

Dalam "country assistance policies" terkini untuk Indonesia (versi tahun fiskal 2012), ditekankan bahwa hubungan kerja sama ekonomi dengan Indonesia bagi Jepang tetap sangat dalam artinya dan penting karena kedua negara berbagi kepentingan nasional satu sama lain. Sebagai kepentingan nasional Jepang di dalam hubungan eratnya dengan Indonesia, laporan ini merujuk kepada sumber daya alam seperti LNG, 
batu bara, bahan mineral seperti perunggu, nikel dan lain-lain. Laporan ini juga menekankan bahwa hubungan ekonomi antara kedua negara tersebut harus diperkuat melalui kerja sama pembangunan, terutama di bidang pembangunan infrastruktur, yang merupakan salah satu masalah utama pembangunan di Indonesia (MOFA, 2012:12). Sesuai dengan prinsip dasar kebijakan ODA Jepang di Indonesia, yaitu "Bantuan untuk pembangunan sosial berimbang dan peningkatan kemampuan menangani isu-isu baik kawasan Asia maupun masyarakat internasional," kebijakan dasar ODA di Indonesia ditentukan sebagai tiga elemen berikut: Pertama, bantuan untuk pembangunan ekonomi Indonesia (persiapan infrastruktur, perbaikan berbagai sistem/peraturan sosial, perbaikan lingkungan investasi, pembangunan SDM, dan lain-lain). Kedua, bantuan untuk menghapus kesenjangan sosial dan pembangunan masyarakat yang aman (perbaikan transportasi, pembangunan daerah, pencegahan bencana dan lain-lain), dan ketiga, bantuan untuk peningkatan kemampuan menangani isu-isu kawasan Asia dan masyarakat internasional seperti keamanan laut, terorisme, penyakit menular, lingkungan hidup, perubahan iklim dan lain-lain (MOFA, 2012:2). Permasalahan proyek ODA Jepang, apalagi proyek Koto Panjang, tidak ditunjukkan di country assistance policy tersebut secara langsung. Namun sebagai suatu perhatian, tercantum bahwa Jepang harus berupaya untuk melaksanakan proyek dengan baik karena ada kekhawatiran bahwa pelaksanaan proyek oleh pemerintah Indonesia, khususnya prosedur penetapan kebijakan oleh pemerintah yang sangat rumit, dapat menyusahkan serta berpotensi mengakibatkan permasalahan dan memunculkan kerugian bagi masyarakat lokal.

Dalam kasus pembangunan bendungan Koto Panjang, meskipun ada gerakan sosial untuk menuntut pemerintah Jepang dan menolak bantuan ekonomi dari Jepang di sebagian masyarakat Indonesia, terutama di tempat proyek tersebut, pemerintah Indonesia sampai saat ini tidak pernah mengabulkan tuntutan tersebut. Pemerintah Indonesia tidak pernah meminta kepada pemerintah Jepang untuk memberikan kompensasi atau memprotes kebijakan ODA Jepang secara resmi, bahkan tidak pernah menyebutkan permasalahan tersebut kepada pemerintah Jepang di pertemuan-pertemuan resmi. Indonesia bahkan tetap mengekspresikan rasa terima kasih di setiap pertemuan tingkat tinggi dan bersikap "welcome" terhadap bantuan ekonomi Jepang.

Menurut data-data pemerintah dan berita media Indonesia, posisi utang pemerintah dari pinjaman langsung bilateral dan multilateral terus 
bertambah. Hingga akhir Januari 2014, jumlah utang Indonesia mencapai Rp 721 trilyun. Negara yang memberikan pinjaman terbanyak ke Indonesia adalah Jepang. Dari Jepang, total utang yang ditarik Indonesia mencapai Rp 261,21 trilyun. Jumlah ini naik 3,1\% atau $\operatorname{Rp} 7,83$ trilyun dari bulan sebelumnya yang mencapai Rp 253,38 trilyun. Selama ini, pinjaman dari Jepang banyak digunakan untuk membiayai infrastruktur dalam rangka pinjaman Yen ODA dari negara tersebut. Setelah Jepang, negara yang tercatat sebagai pemberi fasilitas pinjaman terbesar ke Indonesia adalah Perancis, dengan nilai pinjaman sebesar Rp 27,1 trilyun, diikuti Jerman dengan $\operatorname{Rp}$ 23,53 trilyun, turun tipis dari akhir Desember 2013 sebesar Rp 23,68 trilyun (Kemenkeu, n.a \& Jatmiko, 2014). Di sini bisa dilihat bahwa bantuan pinjaman ODA Jepang masih sangat besar dan lebih banyak dibanding negara donor yang lain. Hal yang serupa dapat dilihat pada data skema ODA yang lain. Selain pinjaman Yen, bantuan skema yang lain juga tetap dilaksanakan dan jumlahnya tetap stabil secara relatif, tidak merosot drastis.

Dari uraian di atas, bisa disimpulkan bahwa ODA Jepang ke Indonesia masih sangat berperan penting bagi hubungan bilateral kedua negara. Saat ini bantuan ekonomi dari Jepang lebih dipentingkan untuk memperdalam hubungan kedua negara, juga untuk memenuhi kepentingan nasional masing-masing. Sekalipun permasalahan proyek Koto Panjang berdampak terhadap perubahan kebijakan ODA Jepang, dapat dikatakan bahwa dampak dari masalah proyek itu terhadap hubungan Jepang-Indonesia secara langsung tidak terlihat, setidaknya sampai saat ini. Hubungan erat kedua negara, khususnya di bidang kerja sama ekonomi, tetap berjalan; kebijakan ODA berperan penting dalam pembentukan hubungan WIN-WIN antara kedua negara.

Serangkaian peristiwa terkait proyek Koto Panjang tidak menimbulkan ketegangan di antara kedua negara secara politik. Ini karena keuntungan kedua negara yang didapatkan dari ODA atau hubungan kerja sama ekonomi antara kedua negara kini jauh lebih besar daripada kerugian mereka dari proyek Koto Panjang. Dari posisi masyarakat lokal, dampak negatif dari kesalahan dalam pelaksanaan proyek tersebut memang sangat besar dan serius, juga harus dikompensasikan pelaksanaannya. Namun, hal itu tidak sampai berpengaruh kepada hubungan politik antara kedua negara. Kepentingan nasional masing-masing negara membuat gerakan masyarakat lokal hanya sampai menjadi pendorong bagi reformasi sistem ODA Jepang saja. 


\section{Kesimpulan}

Jepang sudah lama memiliki peran penting di dalam masyarakat internasional, khususnya dalam pembangunan negara-negara berkembang melalui pemberian ODA. Kebijakan ODA Jepang ini sangat signifikan bagi strategi diplomasi Jepang karena bagi Jepang kekuatan ekonomi adalah salah satu alat diplomasi terbesar dan terpenting yang dapat mengimbangi tiadanya kekuatan militer yang ia memiliki. Melalui pemberian ODA, Jepang berkontribusi besar dalam pembangunan sosial dan ekonomi negara penerima sekaligus dapat pula menperoleh kepentingan nasional seperti pembangunan kepercayaan dari masyarakat internasional, peningkatan perekonomian nasional, impor sumber daya alam, dan lain-lain.

Kebijakan ODA Jepang adalah salah satu strategi untuk membuat hubungan bilateral yang bersifat WIN-WIN dengan negara-negara penerima. Indonesia, negara dengan potensi ekonomi terbesar di kawasan Asia Tenggara, adalah negara penerima ODA Jepang yang terbesar. Bagi Indonesia sendiri, Jepang adalah negara donor terbesar. Jepang mendukung perkembangan pembangunan Indonesia di berbagai bidang melalui ODA selama lebih dari 50 tahun. Sebagai balasannya, Jepang mendapatkan banyak keuntungan dari Indonesia di bidang keamanan jalur laut, perdagangan, sumber daya alam, dan sebagainya. Kedua negara telah menjadi mitra penting secara timbal-balik. Kerja sama ekonomi melalui ODA telah menjadi kunci utama untuk hubungan bilateral Jepang-Indonesia yang lebih harmonis dewasa ini.

Namun demikian, sebetulnya ODA mempunyai sisi negatif juga. Terutama pada kurun waktu 1980-an dan 1990-an, sebagian proyek ODA menimbulkan berbagai masalah di lapangan dan membuat penduduk lokal menderita dampak negatifnya. Proyek-proyek ini disebut Mondaianken (proyek bermasalah), dan mondai-anken yang paling typical dan kelak memberikan kesempatan untuk perdebatan di masyarakat Jepang adalah pembangunan proyek PLTA Koto Panjang yang dilaksanakan di Provinsi Riau pada tahun 1991-1997.

Masyarakat Koto Panjang bersikap kritis terhadap proyek pembangunan PLTA. Mereka bahkan menilai bahwa ODA Jepang tidak transparan, tidak terbuka untuk partisipasi publik, hanya memberikan dana dan membiarkan negara penerima menangani pelaksanaan proyeknya. PLTA Koto Panjang menjadi proyek pertama dalam sejarah ODA Jepang yang mengakibatkan gugatan oleh penduduk di negara penerima kepada pemerintah Jepang. Perjuangan masyarakat Koto 
Panjang sampai saat ini tidak mendapatkan hasilnya menurut hukum, namun gerakan ini cukup berdampak untuk mengumpulkan perhatian rakyat Jepang terhadap kebijakan ODA negara mereka hingga menjadi pendorong bagi reformasi ODA.

Barangkali bisa dikatakan bahwa demi "kepentingan nasional" yang didapatkan dari kerja sama ekonomi antara kedua negara, kerugian masyarakat lokal dari suatu proyek ODA dapat dikesampingkan. Dalam hal ini masalah yang ditimbulkan oleh sebuah proyek ODA tidak berdampak serius pada hubungan Jepang dan Indonesia karena keduanya lebih mementingkan kepentingan nasional daripada kepentingan sosial individu warga negara masing-masing. Tulisan ini beranggapan bahwa hal ini merupakan sebuah ironi mengingat kepentingan nasional sebetulnya dikejar oleh negara untuk meningkatkan kehidupan dan menjaga keamanan rakyat, yaitu menjaga kepentingan sosial/individu rakyat negara tersebut. Di arena terdepan diplomasi, kadang-kadang kepentingan individu diabaikan dan hanya kepentingan nasional, yang sesungguhnya bertujuan untuk menjaga kepentingan individu rakyat, yang diperhatikan oleh negara. Penulis berharap bahwa ODA Jepang tetap mengandung pandangan dari posisi negara dan posisi rakyat/individu berdasarkan peraturan baru agar kepentingan keduanya tercapai secara adil melalui kebijakan ODA, sehingga ODA Jepang menjadi strategi untuk membuat hubungan bilateral yang bersifat benarbenar WIN-WIN dengan negara-negara penerima. Secara khusus, penulis juga berharap agar masyarakat Koto Panjang dapat segera mendapatkan kehidupan yang nyaman serta berdaulat.

\section{Daftar Pustaka}

Bagian Kerja Sama Internasional Departemen Luar Negeri Jepang (2012) 政府開発援助国別データブック 2012 (ODA Data book 2012). Tokyo, p. 12.

Departemen Luar Negeri Jepang. Tersedia dalam: $<$ http://www.mofa.go.jp/mofaj/area/page3_000594.html> [Diakses 30 Desember 2013].

Departemen Luar Negeri Jepang. Outline of the Country Assistance Policies [Online], Tersedia dalam: <http://www.mofa.go.jp/policy/oda/assistance/ outline_cap.html $>$ [Diakses 21 Februari 2014].

Departmen Luar Negeri Jepang (2007) DAC Evaluation Network, DAC Evaluation Quality Standards, DAC/OECD, Paris [Online]. Tersedia dalam <http://www.mofa.go.jp/mofaj/area/page22_000793.html> [Diakses 1 Februari 2014]. 
Departemen Luar Negeri Jepang. (2013) Japan's ODA White Paper 2013. Tokyo.Iokibe, M. (2010) The Diplomatic History of Postwar Japan. Tokyo: Yuuhikaku Arma.

Japan Inclusive Business Support Center. Tersedia dalam: $<$ http://www.bop.go.jp/bop> [Diakses 1 Februari 2014].

Japan's ODA. Tersedia dalam: http://www.mofa.go.jp/mofaj/gaiko/oda/doukou/kaigi/04asia_kaihatsu_g. html [Diakses 1 Februari 2014].

Jatmiko, B. P. (2014) Indonesia Makin Rajin Utang Ke Jepang [Online], Kompas. Tersedia dalam: $<$ http://bisniskeuangan.kompas.com/read/2014/02/26/1036203/Indonesia. Makin.Rajin.Utang.ke.Jepang> [Diakses 2 Maret 2014].

JICA. Japan's Official Development Assistance [Online]. Tersedia dalam: $<$ http://www.jica.go.jp/english/about/index/html> [Diakses 30 Maret 2013].

Kawata, T. (2003) Dictionary of International Political Economy. Tokyo: Tokyo Shoseki.

Kedutaan Jepang di Indonesia. Bantuan ODA Jepang di Indonesia [Online]. Tersedia dalam: <http://www.id.emb-japan.go.jp/oda/id/index.htm> [Diakses pada 30 Maret 2013].

Kedutaan Besar Jepang di Indonesia. Tersedia dalam: <http://www.id.embjapan.go.jp/oda/id/projects/grassroot/odaprojects_grassroot_ application.htm> [Diakses 1 Februari 2014].

Kementerian Keuangan Republik Indonesia. Tersedia dalam: $<$ http://www.kemenkeu.go.id/katalogdata> [Diakses 2 Maret 2014].

Nishigaki, A. (2009) The Economics of Development Assistance: Japan's ODA in a Symbiotic World. Tokyo: Yuuhikaku.

ODA 見える化サイト (ODA Mieru-kasaito: Lamanvisualisasi ODA) [Online]. Tersedia dalam: <http://www.jica.go.jp/oda/> [Diakses 10 Februari 2014].

PekanBaruRiau.Com (2009) Info Obyek Wisata Riau [Online]. Tersedia dalam: http://www.pekanbaruriau.com/2009/02/ wisata-riau-visit-riau-2009.html [Diakses 14 Januari 2014].

Sim, L.H. (2001) Peranan Jepang di Asia. Jakarta: Gramedia Pustaka Utama.

Sumi, K. (2006) Juminnakase no enjo _ Koto Panjang Dam niyorujinken-shingai to kankyou-hakai (Pelanggaran Hak Asasi Manusia dan Kerusakan Lingkungan dalam Proyek Dam Koto Panjang). Tokyo: Myoso.

Takahashi, N. (2002). The scandal of Japanese aid to Indonesia [Online] Asia Times Online (daring). Tersedia dalam: <http://www.atimes.com/atimes/Japan/DH02Dh01.html> (Diakses 20 Februari 2014).

Tim SAPS JBIC. (2002) Laporan SAPS (Special Assistance for Project Sustainability) Proyek PLTA Koto Panjang. Tokyo. 
Vesky, F.R. (2014) Riwayat Sepuluh Negeri yang Tenggelam. Padang Ekspres, 21 Januari.

Watanabe, S. (2014) 日インドネシア、「2 プラス $2 」$ 早期開催で一致 (Jepang dan Indonesia setuju "2+2" dalam waktu dekat) [Online], Nihon Keizai Shimbun. Tersedia dalam: http://www.nikkei.com/article/ DGXNASDE01006_R00C14A3PE8000/ [Diakses 2 Maret 2014].

Yamamoto, T.

JICAと日本政府のODAが訴えられたコトパンジャンダム訴訟 (Gugatan Koto Panjang, yang JICA dan pemerintah Jepang menjadi tertuduh)" 山本敏晴のブログ(blog Toshiharu Yamamoto) (daring) [Online]. Tersedia dalam:

http://blog.livedoor.jp/toshiharuyamamoto128/archives/65583886.html (Diakses 20 Februari 2014). 